\author{
在宅重度障害児・者の親のレジリエンス尺度の開発 \\ 一その信頼性と妥当性の検討一 \\ 田中 美央 ${ }^{1}$, 久田 満 $^{2}$, 宮坂 道夫 ${ }^{1}$, 倉田 慶子 ${ }^{3}$, 瀧澤 久美子 ${ }^{4}$, \\ 西方 真弓 ${ }^{1}$, 遠山 潤 ${ }^{5}$, 関 奈緒 $^{1}$ \\ 1 新潟大学保健学研究科 \\ 2 上智大学総合人間科学部心理学科 \\ ${ }^{3}$ 東邦大学看護学部看護学科 \\ ${ }^{4}$ 横浜市社会福祉協議会障害者支援センター \\ 5 国立病院機構西新潟中央病院神経小児科
}

\title{
Development of a New Resilience Scale for Parents of Children with Profound Intellectual and Multiple Disabilities —Some Evidence of Reliability and Validity-
}

\author{
Mio TANAKA ${ }^{1}$, Mitsuru HISATA², Michio MIYASAKA ${ }^{1}$, Keiko KURATA³ ${ }^{3}$ Kumiko TAKIZAWA ${ }^{4}$, \\ Mayumi NISHIKATA ${ }^{1}$, Jun TOHYAMA ${ }^{5}$ and Nao SEKI $^{1}$ \\ ${ }^{I}$ Niigata University Graduate School of Health Sciences \\ ${ }^{2}$ Department of Faculty of Human Sciences, Sophia University \\ ${ }^{3}$ Department of Faculty of Nursing, Toho University \\ ${ }^{4}$ Yokohama City Council of Social Welfare \\ ${ }^{5}$ Department of Child Neurology, Nishi-Niigata Chuo National Hospital
}

\begin{abstract}
Objetives: As the first step forward building a supporting system for the Parents of Children with Profound Intellectual and Multiple Disabilities (PIMD) at home, we developed a new resilience scale that can be used by multiple professionals to understand the situation of those parents and to provide the necessary support.

Methods: First, we collected scale items on the basis of our previous study as well as related reports in the literature. These items were then screened by the research team with knowledge and experience in supporting those parents, finally, 37 items were generated. Then, we asked the parents of children with PIMD who were of elementary school age and above in the Kanto-Shinetsu area to complete a questionnaire. Out of 477 questionnaires sent, 193 were refused, and the data were statistically analyzed.

Results: Exploratory factor analysis revealed that the scale was made up of the following seven factors. 1) Understanding and awareness of the child, 2) Empowerment by the child, 3) Use of specialists, 4) Interest and concern in something other than the child, 5) Emotional adjustment, 6) Maintenance of lifestyle balance, and 7) Request for assistances. Cronbach's alpha coefficient of each factor was calculated. The validity was also confirmed by determining the relationship of resilience with parents' well-being.

Conclusions: The results suggest that the new resilience scale for parents of children with PIMD developed in this study can be a reliable instrument for assessing resilience in Japanese parents of a child with such disabilities
\end{abstract}

Key words: Resilience Scale for the Parents of a Child with Profound Intellectual and Multiple Disabilities (重度障害児の親のレジリエンス尺度), questionnaire（質問紙調査）, medical care（医療的ヶア）, home care（在宅生活） 


\section{I. 緒言}

近年の医療の進歩により実用化された様々な医療技術 を用いて，在宅で生活を括くる重度障害児・者が増加し て扣り（1），その支援が喫緊の課題となっている。全国 の新生児集中治療室等に 1 年以上入院している児の実態 調査 (2) では, $98 \%$ が重度の知的障害と重度の肢体不 自由の重複した状態にある重症心身障害児（*欄外注釈） であり，人工呼吸器や胃ろら等を使用し，たんの吸引や 経管栄養等の医療的ケアが必要な状態にあることが報告 されている。こうした背景から, 医療的ヶアが必要な 18 歳未満の者は, 2005 年では 9,000 人程度だったが 2015 年には 17,000 人 (3) と, 10 年間で約 2 倍に増加し ている。また，2016年度の文部科学省の調査 (4) では, 特別支援学級に在籍している医療的ケアが必要な者は 8,116 人抢り, その中で人工呼吸器管理を要する者の割 合は 1,331 名 $(16.4 \%)$ で, 2007 年度の 2 倍の割合となっ ている。成人では医療的ケアのらち在宅人工呼吸器は $4.5 \%$ (5) であり，低年齢ほど人工呼吸器の使用割合が多 く, より重症度の高い者が増加している。新生児仮死や 先天異常を基礎疾患とする長期入院児が，呼吸管理をし ながら在宅医療に移行していること（6）や，年齢を経て も人工呼吸器から離脱できないこと（3）が，その背景と して指摘されている。

一方, 我が国の 2015 年の調査 (7) では, 重症心身障 害児扮よび重症心身障害者* は全国に 51,143 人（対人 口比 $0.040 \%$ ) で，らち施設入所が 15,854 人 $(31 \%)$, 在 宅は 35,289 人 $(69 \%)$ と推定されている。また，生命 予後については，3歳以上を対象に検討した調査による と, 平均生存年齢は 40.3 歳 (8) で, 年々高齢化してい ることが報告されている（9）。以上のことから，在宅生 活を拈くる重度の障害児・者は, 長期に打よぶ濃厚な医 療的ケアを必要とするため, 地域包括ケアのもと医療・ 教育・福祉等の連携による支援体制を構築することが求

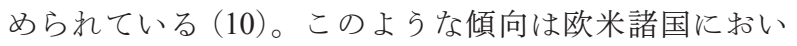
ても同様である $(11)$ 。

重度の障害児・者に関する国内外の文献を概観すると， 子どもの長期的な健康管理や世話に伴ら家族の負担や困 難 $(12-14)$, 母親の燃えつき $(15,16)$, ストレスの高さ (17-20), 疲労 (21-23) 等, 介護する立場にある者（主 に親）の負担やストレスに関するものが多くを占めてい ることが分かる。さらに, 子どもの微細な反応を読み取 ることが難しいために子どものケアを他者に委祀ると に抵抗感を感じることにより，母子分離困難に陥りやす く，社会資源を活用しにくい状況にあることも報告され

受付 2018 年 5 月 14 日, 受理 2018 年 8 月 17 日

Reprint requests to: Mio TANAKA

Faculty of Medicine, Niigata University, 2-746 Asahimachi-dori, Chuo-ku, Niigata 951-8518, Japan

TEL: +81(25)227-0969

E-mail: mio@clg.niigata-u.ac.jp
ている $(2,24)$ 。

こうした背景から，日常的に育児や介護を担ら親への 身体的, 精神的, 社会的なサポートの提供は重要な課題 であるといえるが (25-29)，それに加えて，近年，レジ リエンス $(30,31)$ 等の重要性が報告されている。レジリ エンスとは，「弾力性」や「跳初返す力」を意味する物 理学用語に由来するが，不可避的なストレス状況に曝さ れた人が，精神的に重篤な症状を示すことなく，その状 況を乗り越えたり，心理的に健康な状態へ回復したりす る力を意味するもの（32）として，欧米では 1970 年代よ り保健医療分野で用いられて扣り，近年ではレジリエ ンス概念を用いた介入の有効性を検討する試みも行われ ている。レジリエンスには様々な定義があるが，たとえ ば Masten は，「困難あるいは脅威的な状況にもかかわら ず，らまく適応する過程，能力，あるいは結果」(33) と定義し, 困難な状況から立ち直るプロセスとその結果 の説明までを含めた概念であるとしている。

一方，レジリエンスに関する測定尺度は，レジリエン ス尺度 $(34,35)$ や，我が国では S-Hレジリエンス検査 （36）などが開発されているが，これらの尺度は回答者 （親など）が就業していることを前提とした質問項目が 多く含まれている。育児に専念している親は, 子育てに 特有のストレスを抱えているとされ (37)，親が体験し ている状況が的確に反映されない可能性が指摘できる。 したがって，既存のレジリエンス尺度を用いても，就業 していない親や育児期の親については適切な測定ができ ないことが懸念される。

子育て中の親のレジリエンスに焦点を当てた海外の研 究としては，発達障害児を育てる母親 $(38,39)$ や小児が 几等の慢性疾患のある子どもの親 (40-42) を対象にした ものが散見される。それらの中でも, 子育てに拉いては 親のレジリエンスが重要であること (43), レジリエン スは発達させることが可能であること(44), レジリエ ンスは人生の課題の達成, 困難への対処, 本人にとって 望ましい育児等を促進することが報告されている(44)。 さらには，レジリエンスを備えている親は育児ストレス が低く, 首尾一貫感覚が高くなるといら知見も見出され て扣り (45)，小児がん領域ではレジリエンス概念を用 いて親への支援プログラムを開発しその評価を行ってい る例もある(46)。

一方, 国内に拈いては, Baraitser \& Noack(47) らの「子 育てレジリエンス」の概念に依拠した「子育てレジリエ ンス尺度」（48）を尾野らが開発し，宮野らは母親だけ でなく父親の活用も目指した「養育レジリエンス尺度」 を開発している (49)。それらの尺度を用いた研究から， レジリエンスの高い母親は育览負担感が低く，自己効力

*重症心身障害児・者 : 重症心身障害児（児童福祉法第 43 条の 4）は，重度の知的障害及び重度の肢体不自由が重複した状態 にある満 18 歳未満の者, 同様の障害をもつ満 18 歳以上の者は 重症心身障害者（児童福祉法第 63 条の3） と定義され，児童 福祉法では児・者一貫の扱いとなっている現状 (2) がある。 
感が高く，精神的健康度が高いこと，あるいはレジリエ ンスは子ぞもの人数や成長に影響されることがなく，母 親の年齢によって発達し, 障害種別にみると, ダウン症, 自閉症, 知的障害の順に子育てレジリエンス得点が減少 することが報告されている(50)。

しかし, これらの尺度は, 乳幼児期から学童期の子ど もを育てる親を対象として扣り, 乳幼児期から青年期, 成人期へと長期にわたってケアが継続する在宅重度障害 児・者の親の状況の把握には必ずしも適切であるとは言 い難い項目が含まれている。子どもの障害という現実に 直面した親が，種々の資源を活用し適応するプロセスを 考慮する必要があり $(51,52)$, また学童期 (小学生) 以降 の重度障害児・者と親のライフステージに打ける発達課 題を達成するためにも, 生涯にわたる継続的な支援のあ り方を検討することが重要と考える。しかしながら, 重 度障害児・者の親を対象にした，レジリエンスに関する 研究は殆ど行われていない。従って, 新たに尺度を開発 することは，冒頭で述べたよらな支援体制の構築に向け て, 大いに意義があるものと考えられる。な物, 本研究に 扣いて, 重度障害児・者とは,「肢体不自由と重度の知的 障害の重複した状態にある者」もしくは「日常生活を営 むために医療を要する状態 (53) にある者」と定義する。

\section{II. 研究目的}

本研究では, 学童期以降の重度障害児・者を在宅でケ アしている親のレジリエンス尺度を開発し, その信頼性 および妥当性を検討することを目的とする。

\section{III. 方 法}

\section{1. 尺度項目の選定}

尺度を構成する項目の選定に当たっては，まず Masten ら（33）の提唱する個人の気質, パーソナリティ, 統制 の所在などを含む「個人的資源」と家族, 友人, 専門家 などからのサポート，モデリングの対象となるよらな人 物の存在といった「環境資源」の 2 つのレシリエンス要 因を上位概念として想定し，それらを具体化したカテゴ リーとして，個人的資源としての［育児スキル，，感情 調整力，，［育児への見通し・希望・期待］を, そして環 境資源としての [援助要請力 $]$ と [対人的支光］を抽出 して項目群を構成した。それらの概念を基に, 研究者ら の質的研究 (52) で語られた対象者の言葉や表現を拾い 上げ，最終的には 81 個の暫定項目を作成した。

各項目内容の妥当性については, 尺度開発の専門家 1 名, 質的研究の専門家 1 名, 障害児看護および看護学 を専門とする看護教員 6 名で, 選定した項目がレジリエ ンスの概念として適切かどらか検討した。さらに, 障害 児医療経験 25 年以上の医師 1 名, 障害児福祉分野の経 験 40 年以上の福祉職 1 名, 心理学研究者 1 名, 小児・ 母性看護学領域の大学教員 3 名, 当事者の重度障害児・
者の母親 4 名とともに, 妥当性について繰り返し検討を 行った。そのらえで, 既存のレジリエンス尺度に見られ るよらな, 仕事上の出来事や類似場面，あるいは特殊な 場面を想定した項目を除外し，最終的には 37 個の尺度 項目に絞り込んだ。

\section{2. 調査方法 \\ 1) 調査対象者}

関東甲信越地域の通院 - 通所施設 2 施設, 特別支援学 校 3 校, 親の会 2 団体に所属している障害児・者の父親 または母親を対象者とした。我が国の在宅重度障害児・ 者の実数は, 身体障害者手帳や当事者団体, 医療機関や 福祉サービス事業所, 訪問看護事業所の利用状況などか ら推定されているが，支援サービスを利用していない家 族が 8 割を超えて招り (1), 実数把握が難しい状況があ るため, 無作為抽出は困難であると判断した。対象者の 選択に関して,レジリエンスはケアの経験を通して獲得 する側面も大きく (47), 子ぞもが学童期以上かつ発症・ 診断後 1 年以上経過している障害児・者の親とした。さ らに, 我が国の重度障害児・者への支援システムには地 域差が大きいため, 単一地域ではなく, 首都圏と地方都 市が複数含まれるよら考慮して医療教育福祉機関の選出 を行い, サンプリングの偏りを最小限にするよう努めた。

\section{2) 調査方法}

調査は，無記名自記式質問票を用いて行った。質問票 は，上記の施設や団体の責任者および研究協力者を通じ て対象者に配布した。その際, 研究協力者が, 先に述べ たよらな基準に照らして適格かどらかを判断し，研究の 趣旨と内容を口頭で説明して，対象者の同意を得たうえ で回答を依頼した。回答後の質問票は, 返信用封筒に厳 封し，投函する方法で回収した。データ収集期間は， 2017 年 12 月〜 2018 年 1 月であった。

\section{3) 調査項目}

(1)基本属性: 親の年齢, 性別, 子ぞもの数, 家族形態, 当該児以外のケア状況, 就業状況, 家庭でのケア内容に ついて情報を収集した。

(2)子どもの状態: 鈴木らの超重症児（者）スコア（54） を用いて把握した。これは25 点以上を超重症児, 24 10 点を準超重症児とするものである。また, 子どもの 年齢, 性別, 診断年齢, 医療的ヶア内容, 療育・在宅支 援サービス等の利用経験，コミュニケーション能力に関 する情報も収集した。

(3)重度障害児・者の親のレジリエンス尺度 : 先に述べ た暫定 37 項目に対して,「十分できているー5 点」から「で きていないー1 点」の 5 件法で回答を求めた。得点が高 いほどレジリエンスが高いことを意味する。

(4)親のウェルビーイング:田中ら（55）が作成した「改 定一いきいき度尺度」を用いた。これは, 20 歳代から 60 歳代のウェルビーイングを測定する目的で作成され た尺度であり，信頼性拈よび妥当性を有していることが 確認されている。この尺度の 4 つの下位尺度のらち,「満 
足感 (4 項目)」扎よび「チャレンジ精神 (4 項目)」を 使用した。これらの項目に対して，「かなりそら思う一 4 点」から「そら思わない一 1 点」までの 4 件法で回答を 求めた。得点が高いほどウェルビーイングの状態が良い ことを示す。本尺度は，WHO の定義に基づいた主観的 ウェルビーイングを肯定的側面と否定的側面の二次元か ら捉えることができる尺度であるが，回答者にとって不 快感などのネガティブな感情が生じないよう，肯定的な 項目に絞り，8 項目と数少ない項目により測定が可能で あるため,「満足感」と「チャレンジ精神」を用いた。

\section{4）分析方法}

まずはじめに，天井効果と床効果を検討するために， 各項目ごとに平均值と標準偏差を算出した。また, 信頼 性の検討のために，各下位尺度のクロンバックのアル ファ係数を算出した。妥当性の検討（56）については, 構成概念妥当性にすべての妥当性は収斂するという, 最 近の心理測定学に打ける尺度作成に関する考方方 (57) に基づき分析を進めた。まず尺度の内容をより詳細に分 析するための因子分析を行い, 抽出された因子の命名を 行った。また, 重度障害児・者の親のレジリエンス尺度 の下位尺度と親のウェルビーイングとのピアソンの相関 係数を算出し関連性を検討した。

\section{5）倫理的配慮}

調査の実施に先駆けて, 対象施設の代表者もしくは責 任者, 研究協力者に説明を行って承諾を得た。対象者に は, 研究の趣旨と方法, 自由意思による参加と同意の撤 回, 個人情報の保護, 匿名性の確保, 結果の公表などに ついて文書で説明し，質問紙の返信をもって研究参加の 同意とみなした。な报, 本研究は, 新潟大学における「人 を対象とする研究等倫理審査委員会」の承認を得て実施 した（2017年 9 月 22 日，承認番号 2017-0144）。

\section{IV. 結果}

\section{1. 回答者の基本属性}

477 名の親に調查用紙を配布し, 郵送法にて 229 部（回 収率 48.0\%）が回収された。そのらち重度障害児・者の 親のレジリエンス尺度のすべての項目に回答した 193 名 のデータを分析の対象とした。Table 1 に示したように, 回答者は母親 183 名 $(94.8 \%)$, 父親 10 名 (5.2\%) であっ た。平均年齢は $48.9 \pm 6.9$ 歳で， 40 ・50 歳代が $64 \%$ を 占めていた。既婚者は 165 名 $(85.5 \%)$ で，当該児・者 以外之の同居状況は，配偶者 164 名 $(85.0 \%)$, 親 30 名 (15.5\%) であった。また，当該児・者以外で介護の必 要な人がいると答えた人は 24 名 $(12.4 \%)$ であった。 就労状況をみると, 常勤と非常勤（契約，パート，アル バイト）を合わせて 51 名（26.4\%）が仕事をしていた。

\section{2. 重度障害児・者の基本属性}

Table 2 に重度障害児・者の特徵を示した。性別は, 男 93 名 (48.2\%), 女 100 名 $(51.8 \%)$ であった。平均
Table 1 回答者の基本属性（ $\mathrm{n}=193)$

\begin{tabular}{|c|c|c|c|}
\hline & 項目 & 人数（人） & $(\%)$ \\
\hline \multirow{2}{*}{ 回答者 } & 母親 & 183 & 94.8 \\
\hline & 父親 & 10 & 5.2 \\
\hline \multirow{6}{*}{ 親の年齢 } & \multicolumn{3}{|c|}{ 平均 48.9 歳 \pm 6.9} \\
\hline & 30 歳代 & 8 & 4.1 \\
\hline & 40 歳代 & 69 & 35.8 \\
\hline & 50 歳代 & 55 & 28.5 \\
\hline & 60 歳代 & 10 & 5.2 \\
\hline & 無回答 & 51 & 26.4 \\
\hline \multirow{4}{*}{ 婚姻状況 } & 既婚 & 165 & 85.5 \\
\hline & 離婚 & 19 & 9.8 \\
\hline & 死別 & 7 & 3.6 \\
\hline & 無回答 & 2 & 1.0 \\
\hline \multirow{3}{*}{$\begin{array}{l}\text { 同居家族 } \\
\text { (回答者から見た属性) } \\
\text { (複数回答) }\end{array}$} & 配偶者 & 164 & 85.0 \\
\hline & 親 & 30 & 15.5 \\
\hline & その他 & 4 & 2.1 \\
\hline \multirow{3}{*}{$\begin{array}{l}\text { 当該児・者以外で介護 } \\
\text { の必要な人の有無 }\end{array}$} & 有 & 24 & 12.4 \\
\hline & 無 & 163 & 84.5 \\
\hline & 無回答 & 6 & 3.1 \\
\hline \multirow{3}{*}{ 就労状況 } & 常勤 & 13 & 6.7 \\
\hline & $\begin{array}{l}\text { パート・アルバイト・ } \\
\text { その他 }\end{array}$ & 38 & 19.7 \\
\hline & 無職 & 142 & 73.6 \\
\hline
\end{tabular}

年齢は $17.5 \pm 8.4$ で， 30 歳未満が $90 \%$ 以上を占めた。 発症時期は，出生時と乳児期が 163 名 (84.5\%)，幼児 期 20 名（10.4\%）であった。超重症児（者）スコア（55） が 25 点以上の超重症児が 68 名 $(35.2 \%) ， 10 \sim 24$ 点の 準超重症児が 59 名 (30.6\%) で，両者をあわせると全 体の 66\% を占めた。医療的ケアの状況をみると，経鼻・ 経管栄養 123 名 $(63.7 \%)$ が最も多く, 気管切開 80 名 $(41.5 \%)$, 人工呼吸器 80 名 $(41.5 \%)$ であった。

\section{3. 天井効果と床効果の検討}

暫定 37 項目への回答の平均值は， $2.38 \sim 4.68$ 点，標 準偏差は $0.56 \sim 1.27$ であった（Table 3)。天井効果（平 均值＋標準偏差以上）拈よび床効果（平均値一標準偏差 以下）を検討した結果，まず天井効果が見られた「31. 子どもがかわいいと感じられる」,「32．子どもは私に（普 通の育児では経験できないような）たくさんのことを教 えてくれたと感じられる」，「33．子どもの沶かげで自分 自身の成長があると思える」の 3 項目を除外し，34 項 目を採用した。「34. 子どもの抎かげで強くなった部分 もあると感じる」「35. 子どもの成長に励まされている と思える」「36. 子どもが生まれてきたことに意味があ ると感じることができる」についても，天井効果が認め られたが，本尺度が重度障害児・者の親のレジリエンス を測定する目的であり，項目の解釈がレジリエンスを的 確に反映している（56）重要な内容であることから，敢 えて除外しなかった。一方，床効果は認めなかった。 
Table 2 重度障害児・者の基本属性（ $\mathrm{n}=193 ）$

\begin{tabular}{|c|c|c|c|}
\hline & 項目 & 人数 & $(\%)$ \\
\hline \multirow{2}{*}{ 性別 } & 男 & 93 & 48.2 \\
\hline & 女 & 100 & 51.8 \\
\hline \multirow{9}{*}{ 年齢 } & \multicolumn{3}{|c|}{ 平均 17.5 歳 \pm 8.4} \\
\hline & 6-9 歳 & 33 & 17.1 \\
\hline & 10-14 歳 & 49 & 25.4 \\
\hline & 15-19 歳 & 45 & 23.3 \\
\hline & 20-24 歳 & 32 & 16.6 \\
\hline & $25-29$ 歳 & 19 & 9.8 \\
\hline & 30-34 歳 & 5 & 2.6 \\
\hline & 35 歳以上 & 7 & 3.6 \\
\hline & 無回答 & 3 & 1.6 \\
\hline \multirow{6}{*}{$\begin{array}{l}\text { 重症度 } \\
\text { (超重症児・ } \\
\text { 者スコア) }\end{array}$} & 25 点以上（超重症児・者） & 68 & 35.2 \\
\hline & 10-24 点（準超重症児・者） & 59 & 30.6 \\
\hline & $9-1$ 点 & 55 & 28.5 \\
\hline & $\begin{array}{l}0 \text { 点 (運動機能座位まで・医 } \\
\text { 療的ケア無) }\end{array}$ & 3 & 1.6 \\
\hline & $\begin{array}{l}\text { スコア該当なし（運動機能歩 } \\
\text { 行可・医療的ケア有） }\end{array}$ & 7 & 3.6 \\
\hline & 無回答 & 1 & 0.5 \\
\hline \multirow{9}{*}{$\begin{array}{l}\text { 医療的ヶア } \\
\text { (複数回答) }\end{array}$} & 人工呼吸器 & 80 & 41.5 \\
\hline & 気管切開 & 80 & 41.5 \\
\hline & 酸素療法 & 43 & 22.3 \\
\hline & 鼻咽頭エアウェイ & 8 & 4.1 \\
\hline & 栄養経口摂取（全介助） & 82 & 42.5 \\
\hline & 経鼻・胃ろら栄養 & 123 & 63.7 \\
\hline & 腸ろう・腸管栄養 & 34 & 17.6 \\
\hline & IVH（中心静脈栄養） & 3 & 1.6 \\
\hline & 導尿 & 16 & 8.3 \\
\hline \multirow{2}{*}{$\begin{array}{l}\text { 利用経験 } \\
\text { (複数回答) }\end{array}$} & $\begin{array}{l}\text { 通園・療育センタ一利用経験 } \\
\text { 有 }\end{array}$ & 154 & 47.5 \\
\hline & 母子・親子入園利用経験有 & 36 & 11.1 \\
\hline \multirow{5}{*}{$\begin{array}{l}\text { 発症時期 } \\
\text { (重複選択 } \\
\text { あり） }\end{array}$} & 出生時から & 120 & 62.2 \\
\hline & 乳児期から & 86 & 22.3 \\
\hline & 幼児期から & 20 & 10.4 \\
\hline & 学童期 (小学校入学) 以降 & 3 & 1.6 \\
\hline & 無回答 & 7 & 3.6 \\
\hline
\end{tabular}

\section{4. レジリエンス尺度項目の因子分析結果}

残りの 34 項目に対して探索的因子分析（最尤法プロ マックス回転）を行い，固有值掞よびスクリープロット を参考に， 7 因子解が妥当であると判断した。項目の選 択基準は因子負荷量 0.4 とし，それ未満の項目を順次削 除し，さらに二重負荷項目を削除した結果，7因子 28 項目が抽出された（Table 4)。

I 因子は 5 項目から構成され，親が重度障害児・者を 客観視して, 子どもの楽しみや成長をとらえる内容と見 なされたため，〔子どもに対する理解と気づき〕とした。 II因子は 4 項目から構成され, 親が子どもから育児やケ アを肯定的に受け止める心理的動機付けを得たり, 励及 となったりする内容であり，〔子ども自身からのエンパ
ワメント】とした。III⿴囗大因は，4 項目から構成され，支 援が必要な時に専門職を活用するだけでなく，信頼でき る専門職を見極め，情報の取捨選択を行いらまく活用す る内容であり，〔専門職の活用〕とした。IV因子は 4 項 目から構成され, 親が自分自身の生活の中に趣味や楽し 又を見出したり，自分なりに将来について考える時間や 機会をもつなど，自分らしい時間を過ごしたり，行動を 伴わなくとも考光る機会をもつことを示す内容と捉光, 〔子ども以外の興味関心〕とした。V因子は 4 項目から 構成され，心理的に摇らぐ状況の中で，重度障害児・者 の状況やケアを行らことを受け入れるために自分と折り 合いをつける要素, そして困難な状況に主体的に対処す るために時に気持ちを切り替えたり, 落ち着かせたりし ながら，あきらめとマイペースな姿勢を大切にしている 内容であり，〔感情調整〕とした。VI因子は４項目から 構成され，親が重度障害児・者の体調を安定させるため のスキルと知識を有している内容であり，柔軟に家族の 生活パターンに統合して，子どもへのケアを提供・実践 している内容であることから，〔子どもと家族の生活の 安定」と命名した。VII因子は 3 項目から構成され, 親と して，子ぞもの援助を依頼する重要性を見出し，状況に より頼る相手を変えながら調整し, 対応していることか ら〔援助要請〕とした。

\section{5. 信頼性の検討}

信頼性については，クロンバックのアルファ係数を算 定することで検討し,アルファ係数は因子 1 〜 7 の順に, 0.836, 0.861, 0.832, 0.767, 0.807, 0.718, 0.800 であった。

\section{6. 妥当性の検討}

重度障害児・者の親のレジリエンス尺度の 7 つ下位 尺度得点と, 親のウェルビーイングとして, 満足感との 相関係数をみると, 最少 0.281 から最大 0.529 の範囲の 有意な相関がみられた。次にチャレンジ精神との相関係 数をみると, 最少 0.202 から最大 0.500 の範囲の有意な 相関がみられた（Table 5)。

\section{V. 考察}

本研究は,「在宅重度障害児・者の親のレジリエンス 尺度」の開発を行った。本章では, 尺度の信頼性および 妥当性について考察を行ら。

\section{1. 対象者の適切性}

本研究における重度障害児・者の平均年齢は $17.5 \pm 8.4$ 歳で, 30 歳未満が 90\% 以上を占めた。発症時期（重複 回答あり）は，乳児期までが 163 名 $(84.5 \%)$ で，幼児 期が 20 名（10.3\%）であった。超重症児（者）スコア が 25 点以上の超重症児が 68 名 $(35.2 \%), 10 \sim 24$ 点の 準超重症児が 59 名 (30.6\%) で，両者をあわせると全 体の約 66\%を占めた。医療的ケアの状況をみると，経 
Table 3 重度障害児・者の親のレジリエンス尺度の記述統計量 $(\mathrm{n}=193)$

\begin{tabular}{|c|c|c|c|c|c|}
\hline 項目番号 & 項目 & 平均值 & 標準偏差 & 最小值 & 最大值 \\
\hline 1 & 子どもの苦痛が生じないように周りの環境を整える & 4.00 & 0.61 & 1.00 & 5.00 \\
\hline 2 & わが子なりの身体的に安定した状態を保つ & 4.12 & 0.56 & 2.00 & 5.00 \\
\hline 3 & 我が家なりの生活リズムや生活パターンをつくる & 4.20 & 0.57 & 2.00 & 5.00 \\
\hline 4 & 自分なりに必要な情報とそうでない情報を選べる & 3.82 & 0.67 & 1.00 & 5.00 \\
\hline 5 & 子どもの苦痛を感じとる & 3.88 & 0.65 & 2.00 & 5.00 \\
\hline$\underline{6}$ & 子どものお世話にこれまでの経験を活かすことができる & 3.63 & 0.81 & 1.00 & 5.00 \\
\hline$\underline{7}$ & この子がこれからどんな医療ケアが必要になるか予測する & 4.19 & 0.62 & 2.00 & 5.00 \\
\hline 8 & 信頼できる専門職には子どもの状態を説明する & 3.89 & 0.83 & 1.00 & 5.00 \\
\hline 9 & 必要に応じて必要な専門職を活用する・依頼する & 3.90 & 0.79 & 1.00 & 5.00 \\
\hline 10 & 信頼できる専門職に自分の希望を伝える & 2.38 & 1.21 & 1.00 & 5.00 \\
\hline 11 & 必要に応じて家族以外の友人や近所の人などに助けを求める & 3.16 & 1.27 & 1.00 & 5.00 \\
\hline 12 & 家族以外の人に自分の子ぞもを任せる & 3.13 & 1.18 & 1.00 & 5.00 \\
\hline 13 & 必要に応じて頼る相手を変える & 3.76 & 0.84 & 1.00 & 5.00 \\
\hline$\underline{14}$ & 信頼できる仲間から必要な情報を得る & 3.73 & 0.76 & 1.00 & 5.00 \\
\hline$\underline{15}$ & がんばりすぎないようにする & 3.36 & 0.97 & 1.00 & 5.00 \\
\hline 16 & 子育て以外に没頭できる楽しみを持つ & 3.10 & 1.22 & 1.00 & 5.00 \\
\hline 17 & 扤子さん以外との家族との時間も大切にする & 3.33 & 0.99 & 1.00 & 5.00 \\
\hline$\underline{18}$ & ストレスを解消する & 3.18 & 1.06 & 1.00 & 5.00 \\
\hline 19 & なるようにしかならないと思う & 3.75 & 0.91 & 1.00 & 5.00 \\
\hline 20 & いろんなことから吹っ切れたと思える & 3.45 & 0.92 & 1.00 & 5.00 \\
\hline 21 & 自分なりのペースを大切にする & 3.61 & 0.87 & 1.00 & 5.00 \\
\hline 22 & 気持ちにゆとりをもつ & 3.21 & 0.99 & 1.00 & 5.00 \\
\hline 23 & 将来の自分の人生を考える & 2.58 & 1.10 & 1.00 & 5.00 \\
\hline 24 & 子育て以外に将来やってみたいことが思いつく & 2.77 & 1.22 & 1.00 & 5.00 \\
\hline$\underline{25}$ & 自分の子ぞもなりの成長があることに気づく & 4.14 & 0.71 & 1.00 & 5.00 \\
\hline 26 & 子どもには私の知らない世界があることが理解できる & 3.83 & 0.86 & 1.00 & 5.00 \\
\hline 27 & 子ぞも同士のふれあいがわが子の成長につながっていると理解できる & 4.13 & 0.91 & 1.00 & 5.00 \\
\hline 28 & 子どもが楽しんでいることがわかる & 4.24 & 0.71 & 2.00 & 5.00 \\
\hline 29 & 子どもと一緒に楽しい時間が持てる & 4.00 & 0.78 & 2.00 & 5.00 \\
\hline 30 & 子どもの自慢できるところに気づく & 4.12 & 0.77 & 2.00 & 5.00 \\
\hline$\underline{31}$ & 子どもがかわいいと感じられる & 4.68 & 0.56 & 2.00 & 5.00 \\
\hline$\underline{32}$ & 子ぞもは私にたくさんのことを教えてくれたと感じられる & 4.62 & 0.64 & 1.00 & 5.00 \\
\hline$\underline{33}$ & 子どもの扮かげで自分自身の成長があると思える & 4.49 & 0.69 & 2.00 & 5.00 \\
\hline 34 & 子どもの怙かげで強くなった部分もあると感じる & 4.54 & 0.66 & 2.00 & 5.00 \\
\hline 35 & 子ぞもの成長に励まされていると思える & 4.32 & 0.74 & 2.00 & 5.00 \\
\hline 36 & 子どもが生まれてきたことに意味があると感じることができる & 4.37 & 0.86 & 1.00 & 5.00 \\
\hline 37 & 子どもの成長を目標にがんばれる & 3.95 & 0.94 & 1.00 & 5.00 \\
\hline
\end{tabular}

・重度障害児者の親のレジリエンス尺度暫定 37 項目の分類 (1) - (7)：育児スキル，(8)-(14)：援助要請力，(15)-(24)：感情調 整力，(25）-(37）：育児への見通し・希望・期待

・最終的に採用された項目は，番号に下線がある項目を除いた 28 項目

管（経鼻・経管・胃ろら・腸ろら）栄養 157 名（81.3\%） が最も多く，気管切開 80 名 $(41.5 \%)$, 人工呼吸器 80 名 $(41.5 \%)$ であった。以上の特徴を既存の調査と比較 すると，発症年齢は乳児期が最も多いといら當山 (58) や北往 (59) の報告とほぼ一致する。また, 子どもの年 齢については，重度障害児や日常的に医療を要する状態 にある医療的ケア児が増加しているといら報告 $(60,61)$ のと打り，12〜15 歳前後の児が多かった。また，30 歳 を過ぎると在宅率が低下寸るといら難波らの報告 (62)
とも一致していた。その反面，重症度をみると，重症度 区分で準超重症児は超重症児の 1.19 倍という報告 (54) と比較して，本研究では超重症児の方が多く，より重症 度の高い集団であることが分かる。その理由として，本 研究では研究対象者 (親) のリクルートを通院・通所施 設，特別支援学校，親の会で行ったが，この中の首都圏 の通院・通所施設, 特別支援学校は比較的重症度の高い 児・者とその親が利用して拈り，このことが反映された からではないかと考觉らる。しかし，本来，レジリエ 
Table 4 重度障害児・者の親のレジリエンス尺度の因子分析（Promax 回転後）

\begin{tabular}{|c|c|c|c|c|c|c|c|}
\hline 項目内容 & I & II & III & IV & $\mathrm{V}$ & VI & VII \\
\hline \multicolumn{8}{|l|}{ 子どもに対する理解と気づき $(\alpha=0.836)$} \\
\hline 28 子どもが楽しんでいることがわかる & 0.93 & -0.07 & -0.05 & 0.03 & 0.03 & -0.07 & 0.00 \\
\hline 30 子ぞもの自慢できるところに気づく & 0.73 & 0.06 & 0.05 & 0.01 & -0.11 & 0.09 & -0.13 \\
\hline 27 子ども同士のふれあいがわが子の成長につながっていると理解できる & 0.73 & 0.00 & 0.02 & 0.01 & 0.03 & -0.12 & 0.15 \\
\hline 29 子ぞもと一緒に楽しい時間が持てる & 0.69 & 0.06 & -0.10 & -0.05 & -0.04 & 0.27 & -0.02 \\
\hline 26 子どもには私の知らない世界があることが理解できる & 0.52 & -0.04 & 0.01 & 0.07 & 0.09 & -0.17 & 0.14 \\
\hline \multicolumn{8}{|l|}{ 子ども自身からのエンパワメント $(\alpha=0.861)$} \\
\hline 35 子どもの成長に励まされていると思える & 0.05 & 0.88 & 0.03 & -0.06 & 0.06 & -0.09 & 0.00 \\
\hline 36 子どもが生まれてきたことに意味があると感じることができる & -0.09 & 0.83 & 0.01 & 0.09 & -0.08 & 0.01 & -0.02 \\
\hline 37 子どもの成長を目標にがんばれる & -0.02 & 0.80 & -0.06 & 0.03 & -0.06 & 0.07 & 0.09 \\
\hline 34 子どものおかげで強くなった部分もあると感じる & 0.08 & 0.63 & 0.09 & -0.06 & 0.18 & -0.01 & -0.10 \\
\hline \multicolumn{8}{|l|}{ 専門職の活用 $(\alpha=0.832)$} \\
\hline 10 信頼できる専門職に自分の希望を伝える & 0.07 & -0.06 & 0.89 & 0.03 & 0.01 & 0.00 & -0.01 \\
\hline 9 必要に応じて必要な専門職を活用する・依頼する & -0.05 & 0.02 & 0.85 & 0.00 & -0.09 & 0.02 & 0.10 \\
\hline 8 信頼できる専門職には子どもの状態を説明する & 0.01 & 0.04 & 0.63 & -0.14 & 0.14 & 0.12 & 0.09 \\
\hline 4 自分なりに必要な情報とそうでない情報を選べる & -0.11 & 0.08 & 0.45 & 0.08 & -0.03 & -0.01 & 0.09 \\
\hline \multicolumn{8}{|l|}{ 子ども以外の興味関心 $(\alpha=0.767)$} \\
\hline 23 将来の自分の人生を考学る & -0.01 & 0.01 & 0.03 & 0.96 & -0.12 & -0.09 & -0.04 \\
\hline 24 子育て以外に将来やってみたいことが思いつく & 0.05 & -0.01 & 0.08 & 0.69 & 0.00 & -0.16 & 0.02 \\
\hline 17 打子さん以外との家族との時間も大切にする & 0.05 & 0.00 & -0.21 & 0.49 & 0.07 & 0.18 & 0.14 \\
\hline 16 子育て以外に没頭できる楽しみを持つ & -0.02 & 0.05 & 0.02 & 0.45 & 0.12 & 0.07 & 0.11 \\
\hline \multicolumn{8}{|l|}{ 感情調整（ $\alpha=0.807 ）$} \\
\hline 19 なるよらにしかならないと思う & -0.02 & 0.06 & -0.13 & -0.13 & 0.81 & -0.07 & 0.10 \\
\hline 20 いろんなことから吹っ切れたと思える & 0.04 & 0.01 & 0.13 & 0.01 & 0.80 & -0.10 & -0.11 \\
\hline 22 気持ちにゆとりをもつ & -0.04 & 0.01 & -0.01 & 0.36 & 0.53 & 0.03 & -0.09 \\
\hline 21 自分なりのペースを大切にする & 0.01 & -0.10 & 0.04 & 0.10 & 0.53 & 0.32 & 0.00 \\
\hline \multicolumn{8}{|l|}{ 子ぞもと家族の生活の安定 $(\alpha=0.718)$} \\
\hline 2 わが子なりの身体的に安定した状態を保つ & -0.16 & -0.04 & -0.05 & 0.02 & 0.02 & 0.67 & 0.12 \\
\hline 3 我が家なりの生活りズムや生活パターンをつくる & -0.02 & -0.02 & -0.02 & -0.20 & 0.00 & 0.65 & 0.12 \\
\hline 1 子どもの苦痛が生じないように周りの環境を整える & 0.02 & -0.01 & 0.20 & 0.16 & -0.11 & 0.58 & -0.19 \\
\hline 5 子どもの苦痛を感じとる & 0.13 & 0.06 & 0.06 & -0.04 & -0.04 & 0.54 & -0.07 \\
\hline \multicolumn{8}{|l|}{ 援助要請 $(\alpha=0.800)$} \\
\hline 13 必要に応じて頼る相手を変える & 0.08 & -0.03 & 0.12 & 0.03 & -0.07 & 0.01 & 0.81 \\
\hline 12 家族以外の人に自分の子どもを任せる & 0.02 & -0.05 & 0.13 & -0.02 & 0.04 & -0.03 & 0.70 \\
\hline 11 必要に応じて家族以外の友人や近所の人などに助けを求める & 0.01 & 0.11 & -0.05 & 0.13 & -0.01 & 0.13 & 0.59 \\
\hline $\begin{array}{l}\text { 因子間相関 } \\
\end{array}$ & I & II & III & IV & $\mathrm{V}$ & VI & VII \\
\hline I & & 0.44 & 0.32 & 0.04 & 0.08 & 0.30 & 0.20 \\
\hline II & & & 0.45 & 0.26 & 0.19 & 0.33 & 0.19 \\
\hline III & & & & 0.34 & 0.28 & 0.50 & 0.43 \\
\hline IV & & & & & 0.52 & 0.44 & 0.33 \\
\hline $\mathrm{V}$ & & & & & & 0.39 & 0.29 \\
\hline $\mathrm{VI}$ & & & & & & & 0.21 \\
\hline VII & & & & & & & \\
\hline
\end{tabular}

因子負荷量 0.4 以上を太字で表記

採用された項目は暫定尺度 37 項目のうち（6）（7）（14）（15）（18）（25）（31）（32）（33）を除いた28 項目

Table 5 重度障害児・者の親のレジリエンス尺度といきいき度尺度の相関

\begin{tabular}{lccccccc}
\hline & $\begin{array}{c}\text { 子ぞもに対する 子ども自身からの } \\
\text { 理解と気付き } \\
\text { エンパワメント }\end{array}$ & $\begin{array}{c}\text { 専門職の } \\
\text { 活用 }\end{array}$ & $\begin{array}{c}\text { 子ぞも以外の } \\
\text { 興味関心 }\end{array}$ & $\begin{array}{c}\text { 感情調整 } \\
\text { 子ぞもと家族の }\end{array}$ & $\begin{array}{c}\text { 子生活の安定 } \\
\text { 助要請 }\end{array}$ \\
\hline 満足感 & $.285^{* * *}$ & $.510^{* * *}$ & $.405^{* * *}$ & $.529^{* * *}$ & $.281^{* * *}$ & $.358^{* * *}$ & $.301^{* * *}$ \\
チャレンジ精神 & $.202^{* *}$ & $.481^{* * *}$ & $.344^{* * *}$ & $.500^{* * *}$ & $.218^{* *}$ & $.266^{* * *}$ & $.296^{* * *}$ \\
\hline
\end{tabular}

$* * \mathrm{p}<.01 . \quad * * * \mathrm{p}<.001$. 
ンスとは，困難あるいは脅威的な状況に抢いて発揮され るものであり, より重症度の高、集団を対象として尺度 の開発を行らことには大きな意義があると思われる。

\section{2. 重度障害児・者の親のレジリエンス尺度の特徵}

親のレジリエンスについては, 因子分析の結果, 7 因 子が抽出された。このらち，[子どもに対する理解と気 ら゙き］[専門職の活用］[感情調整］[援助要請］は，先 行研究 $(49,50,63)$ で示されたレジリエンスの構成要素 や，定型発達児や発達障害児の親のレジリエンスの要素 と一致した。一方, これまでのレジリエンス尺度には含 まれない因子も見出された。

尾野らの「子育てレジリエンス尺度」との比較では, 〔子 ぞも以外の興味関心]や[子どもと家族の生活の安定] と名付けた因子に相違がみられた。「子育てレジリエン ス尺度」は, Grotberg(64)やHiew (65) のレジリエンス 構成概念に依拠して作成された 3 因子（「ペアレンタル スキル」「ソーシャルサポート」,「母性感情」）からなり, 対象を母親に限定し，母性感情に着目している点が特徵 である。子育て中の母親を対象とした研究だけでなく， 知的障害や自閉症スペクトラム障害のある子どもの母親 を対象とした研究でも用いられている。〔子ども以外の 興味関心〕は，先述したよらに自分らしい時間を過ごし たり，自分のことを考觉る機会の有無を尋水たりする項 目から成るものである。自分自身のことを考えたり楽し んだりする時間を確保することは, 高い相関係数が示す 通り, 親のウェルビーイングの維持にとって重要な要因 であることを示唆する。また，〔子どもと家族の生活の 安定〕は, 尾野らの尺度の「ペアレンタルスキル」と類 似している部分はあるものの, 重度障害児・者の心身の 健康管理や感情をとらえるといらかなり困難な知識と技 術によって，子どもの生活パターンを家族の生活全般の パターンへ統合するという内容で, 重度障害児・者の親 に極めて特徴的な因子であると考觉られる。

一方, 宮野ら（49）の「育児関連レンジリンス尺度」は, 17 項目 3 因子 (「問題解決力」, 「周囲からの支援」,「受 け止め力」）からなる。しかし, 定型発達児の 3 歳児の 親を対象にした研究報告があるものの，障害児の親を対 象とした研究はこれまでのところ報告されていない。育 児関連レジリエンス尺度の「問題解決力」は，本尺度の 〔専門職の活用〕の「自分なりに必要な情報とそうでな い情報を選べる」に対応しているが，医療的ケアが必要 な子どもの場合は，刻一刻と変化する状況に親が見通し をもって対処することが難しく，子育てが期待通りにい かないことで親の育児ストレスが高くなることが報告さ れている(66)。育児の中で積み上げてきた経験を活用 できない状況が生じやすい点で, 重度障害児と定型発達 児の親のレジリエンスを測定する項目が異なってくるの ではないかと推察される。

さらに，下位尺度のうち，〔子ども以外の興味関心〕 と[子ぞも自身からのエンパワメント]は親のウェルビー
イングとの相関が比較的強いことは興味深い。親自身が 子ども以外のことに興味関心をもったり，自分自身の将 来を思考することの重要性が示唆された。長期にケアを 担ら重度障害児・者の親にとって，人生のバランスをと るために必要な視点であり, 重度障害児の親に特徵的な レジリエンス因子と考えられた。一方，障害児の親が子 どもとの関係に価值を置き，ケアに報酬を見出す $(67$, 68）ことや，子どもから育児の心理的支えを得る(52) ことが，国内外で報告されて扣り，この点は親のレジリ エンスにつながる可能性が示唆された。

以上, 本研究で開発された重度障害児・者の親のレジ リエンス尺度は，育児期の親に共通して応用できる因子 を含んではいるものの，従来の尺度では捉えきれなかっ た内容, 即ち〔子ども以外の興味関心〕，〔子ども自身か らのエンパワメント], [子どもと家族の生活の安定], [専 門職の活用]をも含んで抒り，学童期以降の重度障害児・ 者のレジリエンスを多面的に捉え得る尺度であると見な すことができる。

\section{3. 信頼性と妥当性の検討}

本研究で作成した尺度は，因子分析を行い，下位尺度 の項目は 1 項目が当初の項目群の分類以外の項目に移動 しそれ以外の 26 項目はそれぞれもとの分類のままで あった。また，当初の分類内に新たな下位尺度が 2 見

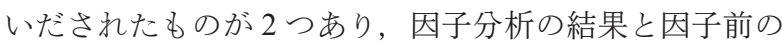
項目群には, ある程度の一致が認められ, 構成概念妥当 性が保持されたと考える。

信頼性は，7つの下位尺度に拈いて，クロンバックの アルファ係数が全て 0.7 以上であった。一般的に, 尺度 得点または項目得点が各対象者に拈いて一貫しているこ とを示すためには 0.7 から 0.8 になるよらに構成される （69）といら見解があり, 内的整合性を確保しているこ とが確認された。よって，本尺度は，全体として信頼性 があるといえる。

また，妥当性の検討には，ウェルビーイングを測定す る「改定一いきいき尺度」の満足感得点（4 項目）打よ びチャレンジ精神（4 項目）を扣き，本尺度の7つの因 子との間に正の相関があると仮定し検討を行った。この 結果, まず満足感との相関係数をみると, 最少 0.281 か ら最大 0.529 の範囲の有意な相関がみられた。次にチャ レンジ精神との相関係数をみると，最少 0.202 から最大 0.500 の範囲の有意な相関がみられた。以上の結果は, レジリェンスとウェルビーイングとの関連性を示した先 行研究 $(48,70,71)$ と一致して扣り, 本尺度の構成概念 妥当性を示唆するものといえる。

\section{VI. 本研究の限界と今後の課題}

本尺度を用いて，重度障害児・者の親のレジリエンス に影響を及ぼす要因を明らかにすることで，多面的な支 援の視点を検討することができるであろう。従来の研究 
では，親の精神的側面である負担感のみに焦点が当てら れることが多かったが，レジリエンスという概念に焦点 を当てて親の状態をアセスメントすることが，親のウェ ルビーイングにつながる可能性が示唆された。重度障害 児・者の親のレジリエンスを促進する，ょり具体的なア プローチの開発や介入の評価ツールとしての活用も期待 できる。

ただし，課題もいくつか挙げられる。まず，本研究は 関東甲信越地域に居住する重度障害児・者の親を対象と したものであり, 得られた結果に地域の特性が反映され た可能性は否定できない。今後は異なった地域に拈いて, 子どもの重症度を考慮しながら本尺度の信頼性や妥当性 を検証していく必要がある。また, 回収率が $48 \%$ 程度 であり，選択バイアスが生じた可能性もある。さらに， 重症度を含む関連要因の検討は今回の研究では行ってお らず，その点を踏まえてどのよらな介入支援が必要かを 検討することが今後の課題である。

今回の分析対象の $95 \%$ が母親であり、レジリエンス の様相が異なると推測できる父親を対象とした研究や, 文化の異なる国との比較研究も将来の課題である。

我が国では, 居住地域によるサービスの偏在や, 独自 のローカルルールの存在により, 限られた資源の中で重 度障害児・者のケアに対応せざるを得ないといら課題が ある。本尺度が，そのよらな課題に対する解決に寄与す ることが期待される。

\section{VII. 結 論}

在宅で重度障害児・者のケアを行っている親 193 名の 調査によって，レジリエンス尺度を開発した。下位尺度 として 7 因子 (28 項目) [子どもに対する理解と気づき], [子ども自身からのエンパワメント]，〔専門職の活用]， 〔子ども以外の興味関心〕，〔感情調整〕，〔子どもと家族 の生活の安定〕、援助要請〕が見いだされた。クロンバッ クのアルファ係数とウェルビーイングとの相関を算出し た結果，本尺度は信頼性扣よび妥当性を有していること が示された。

\section{謝辞}

本研究でアンケートにご協力いただきました皆様，ご 紹介いただきました皆様に深謝いたします。な抏，本研 究は平成 29 年度文部科学省科学研究費補助金（基盤研 究 C 課題番号 $15 \mathrm{~K} 11846$ ）扣よび新潟大学ダイバーシ ティ事業助成を受けて実施した研究の一部である。

利益相反なし

\section{文献}

（1）杉本健郎, 河原直人, 田中英高, 谷澤隆邦, 田辺 功,
田村正徳，他. 日本小児科学会倫理委員会. 超重症心 身障害児の医療的ケアの現状と問題点一全国 8 府県の アンケート調査一. 日本小览科学会誌2008;112:94-101.

（2）楠田 聡. NICU 長期入院児の動態調査 2006. 平成 20 年度厚生労働科学研究費補助金成育疾患克服等次 世代育成基盤研究事業「重症新生児に対する療養・療 育環境の拡充に関寸る総合研究」研究報告書 2008, $1-9$.

（3）奈倉道明．医療的ケア児数と資源把握，平成 28 年度 厚生労働科学研究費補助金障害者政策総合研究事業 「医療的ヶア览に対する実態調査と医療・福祉・保健・ 教育等の連携に関する研究（田村班）」の中間報告.

(4) 文部科学省. 平成 28 年度特別支援学校等の医療的厅 アに関する調査結果について. http://www.mext.go.jp/ a_menu/shotou/tokubetu/material/_icsFiles/afieldfile/ 2017/11/22/1383567_04.pdf (2018.7.24)

（5）田村正徳．医療的ヶア児に対する実態調査と医療，福 祉, 保健, 教育等の連携に関する研究. 厚生労働科学 研究費補助金障害者政策総合研究事業報告書 2016.

（6）森脇浩一，奈倉道明，内田美恵子，田村正徳. 小児在 宅医療の現状と課題 : 小览在宅医療に打ける地域中核 病院の役割: 移行支援, 緊急対応について現状と課題. 小児科臨床 2016;69:13-18.

（7）松葉佐正．重症心身障害児の概念と実態. 小児内科 2015;47(1):1860-1865.

（8）武井理子, 武智信幸, 鈴木康之, 花岡知之. 重症心身 障害児（者）の生命予後について。日本重症心身障害 学会誌 2007;32:147-149.

（9）日本重症心身障害福祉協会. 平成 25（2013）年度超 重症児（者）・準超重症児（者）実態調査集計結果 2013.

（10）大江啓賢，川住隆一．重症心身障害児及び重度・重複 障害児に対する療育・教育支援に関する研究動向と課 題. 山形大学紀要 2014;16(1):47-57.

(11) Cooper SA, Simley E, Finlayson J, Jackson A, Allan L, Williamson A, et al. The prevalence, incidence and factors predictive of mental ill-health in adults with profound intellectual disabilities. J Appl Res Intellect Disabil 2007;20: 493-501.

(12) Farmer JE, Marien WE, Clark MJ, Sherman A, Selva TJ. Primary care supports for children with chronic health conditions identifying and predicting unmet family needs. J Pediatr Psychol 2004;29:355-367.

（13）久野典子，山口桂子，森田チュ子．在宅で重症心身障 害児を養育する母親の養育負担感とそれに影響を与 える要因. 日本看護研究学会雑誌 2006;5:59-69.

（14）山口里美，高田谷久美子，荻原貴子．在宅重症心身障 害児（者）の介護者の精神的健康度と介護負担感を含 屯関連因子の検討. 山梨大学看護学会誌 2005;4:4148.

（15）堀口寿広，加我牧子，宇野 彰，稲垣真澄，秋山千枝 子．発達障害児・者の家族の精神保健，現状と対策に ついて. 脳と発達 1999;31:349-354.

（16）村田恵子，小野智美，草場ヒフミ，有田直子，松田宣 子，大久保法子，他. 慢性的な健康障害をもつ子ども を養育する家族の対処と関連因子．神戸大学医学部保 健学科紀要 1999;15:1-11 
(17) Webster RI, Majnemer A, Platt RW, Shevell MI. Child health and parental stress in school-age children with a preschool diagnosis of developmental delay. J Child Neurol 2008;23:32-38.

（18）山脇明美，村嶋幸代. 重症心身障害児に打忷る在宅支 援サービスの利用に関する研究. 日本公衆衛生学会誌 1998;45:499-511.

（19）善生まり子．重症心身障害児（者）と家族介護者の在 宅介護ニーズと社会的支援の検討. 埼玉県立大学紀要 2006; 7:51-58

（20）戸叶順子. 小児の在宅生活を支援する栃木市福祉卜一 タルサポートセンターに学ぶ. 重症心身障がい児と家 族への在宅生活支援の実際. 訪問看護と介護 2006; 11:126-130.

（21）松岡文香, 明石美子, 岡田豊子, 田上弥生. 短期入所 を利用している重度障害児の母親の育児ストレス及 び疲労感. 日本看護学会論文集 : 小児看護 2005;35: 89-91.

（22）下山郁子. 小児訪問看護への期待. 重症心身障害児・ 者の家族から訪問看護に望みたいこと．訪問看護と介 護 2005;10:200-207.

（23）小西 徹. 障害児・者の地域移行, 在宅サポートと支 援費制度. 小児科 2004;45:1185-1190.

（24）長谷美智子．在宅で生活寸る重症心身障害児の母親の 体調に関する質問紙の開発. 日本重症心身障害学会誌 2010;35:143-150.

(25) Brehaut JC, Kohen DE, Raina P, Walter SD, Russell DJ, Swinton M, et al. The health of primary caregivers of children with cerebral palsy: how does it compare with that of other Canadian caregivers? Pediatrics 2004;114:82-91.

（26）松尾久枝, 加藤孝正. 障害児をもつ母親の養育負担感 にかかわる要因に関する研究社会資源の利用状況を 中心として一. 発達障害研究 1995;16:281-293.

（27）山田陽子．療育機関に通う自閉症スペクトラム児をも つ母親の育児ストレスに関する研究. 川崎医療福祉学 会誌 2010;20:165-178.

（28）湯沢純子，渡邊佳明，松永しのぶ. 自閉症児を育てる 母親の子育てに対する気持ちとソーシャル・サポート の関連. 昭和女子大学生活心理研究所紀要 2007; 10: 119-129.

(29) Armstrong MI, Birnie-Lefcovitch S, Ungar MT. Pathways between social support, family well being, quality of parenting, and child resilience: What we know. J Child Fam Stud 2005;14:269-281.

(30) Gardner J, Harmon T. Exploring resilience from a parent's perspective: a qualitative study of six resilientmothers of children with an intellectual disability. Australian Social Work 2002;55:60-68.

(31) Horton TV, Wallander JL. Hope and social support as resilience factors against psychological distress of mothers who care for children with chronic physical conditions. Rehabil Psychol 2001;46:382-399.

(32) Werner EE. High-risk children in young adulthood: A longitudinal study from birth to 32 years. Am J Orthopsychiatry 1989;59:72-81.

(33) Masten AS, Best KM, Garmezy N. Resilience and development: Contributions from the study of children who over- come adversity. Development and Psychopathology 1990;2: 425-444.

(34) Hiew C, Matchett K. Resilience measurement using a Resilience Scale (SRC). In: Roth R, Farley F (eds), The Spiritual Side of Psychology at Century's End. Lengerich: Pabst Science Publishers, 1999.

(35) Hiew CC, Mori T, Shimizu M. Measurement of resilience development: Preliminary results with a State-Trait resilience inventory. Journal of Learning and Curriculum Development 2000;1:111-117.

（36）佐藤玩志，祐宗省三. レジリエンス尺度の標準化の試 み『S-H式レジリエンス検査（パート1)』の作成打 よび信頼性・妥当性の検討. 看護研究 2009;42:45-52.

（37）杉本令子．育児ストレス・育児ストレス・コーピング に対する研究動向. 日本女子大学大学院人間社会研究 紀要 2008;14:133-147.

(38) Gerstein ED, Crnic KA, Blacher J, Baker BL. Resilience and the course of daily parenting stress in families of young children with intellectual disabilities. J Intellect Disabil Res 2009;53:981-997.

(39) Margalit M, Al-Yagon M, Kleitman T. Family Subtyping and Early Intervention. J Policy Pract Intellect Disabil 2006;3:33-41.

(40) Rosenberg AR, Starks H, Jones B. "I know it when I see it." The complexities of measuring resilience among parents of children with cancer. Care Cancer 2014;22:2661-2668.

(41) Yi-Frazier JP, Fladeboe K, Klein V, Eaton L, Wharton C, McCauley E, et al. Promoting Resilience in Stress Management for Parents (PRISM-P): An intervention for caregivers of youth with serious illness. Fam Syst Health 2017;35: 341-351.

(42) Walsh F. The concept of family resilience: Crisis and challenge. Fam Process 1996;35:261-281.

(43) Heiman T. Parents of children with disabilities: resilience, coping, and future expectations. J Dev Phys Disabil 2002; 14:159-171.

(44) Travis WJ, Combs-Orme T. Resilient parenting: Overcoming Poor Parental Bonding. Soc Work Res 2007;31: 135-149.

(45) Margalit M, Kleitman T. Mothers' stress, resilience and early intervention. Eur J Spec Needs Educ 2006;21:263-283.

(46) Ye ZJ, Qiu HZ, Li PF, Liang MZ, Wang SN, Quan XM. Resilience model for parents of children with cancer in mainland China - An exploratory study. Eur J Oncol Nurs 2017;27:9-16.

(47) Baraitser L, Noack A. Mother courage: Reflections on maternal resilience. Br J Psychother 2007;23:171-188.

（48）尾野明未，奥田訓子，茂木俊彦. 子育てレジリエンス 尺度の作成. ヒューマン・ケア研究 2012;12:98-108.

（49）宮野遊子，藤本美穂，山田純子，藤原千惠子．育児関 連レジリエンス尺度の開発. 日本小児看護学会誌 2014;23:1-7.

（50）尾野明未，茂木俊彦. 障害児を持つ母親の子育てレジ リエンスに関する研究. 心理学研究 2011;2:67-77.

(51) Beth PB, Diane HD, Margaret SM. Life course theory as a framework to examine becoming a mother of a medically fragile preterm infant. Res Nurs Health 2009;32:38-49. 
（52）田中美央，西方真弓，宮坂道夫，倉田慶子，住吉智子. 重症心身障害児の反応に関する母親の内面的支光体 験. 新潟大学保健学雑誌 2017;14:69-77.

（53）改正障害者総合支援法案（正式名称：障害者の日常生 活及び社会生活を総合的に支援するための法律及び 児童福祉法の一部を改正する法律案). 2018 施行. 2016 年 6 月 3 日公布.

（54）鈴木康弘, 武井理子, 武智信幸, 山田美智子, 諸岡美 知子, 平元 東, 他. 超重症児の判定について スコ ア改定の試み。日本重症心身障害学会誌 2008;33:303309.

（55）田中芳幸, 津田 彰, 神宮純江. 改訂いきいき度尺度 の年代差. 久留米大学心理学研究 2006;5:115-123.

（56）久田 満, 北 素子, 谷口千絵. 看護に活かす心理尺 度. 京都：ナカニシヤ出版, 2015, 7-20.

（57）村山 航. 妥当性 : 概念の歴史的变遷と心理測定学的 観点からの考察. 教育心理学年報 2012;51:131-142.

（58）當山真弓，當山 潤，金城陽子. 沖縄県に打汀片側 性痓直型脳性麻痺児の検討。脳と発達 2015;1:242.

（59）北住映二. 医療的ヶアとは. 北住映二, 杉本健郎(編), 新版医療的ケア研修テキスト。京都：クリエイッかも がわ. 2013, 10-23.

（60）平成 27 年度特別支援教育に関する調査の結果について www.mext.go.jp/a_menu/shotou/tokubetu/material/1370505. $\mathrm{htm}$ (2018.5.5 参照)

（61）杉本健郎. 医療的ケア・全国マッピング調査 : 医療的 ケアの必要な人たちへの地域支援ネットワーク創造 のための調査一日本小児神経学会社会活動委員会一. 脳と発達 2014;24:232-236.

（62）難波克雄. 重症心身障害児の概念と定義. 江草安彦監. 重症心身障害児マニュアル第 2 版. 東京 : 医歯薬出版
株式会社, 2005, 8-12.

(63) Turnbull AP. The challenge of providing comprehensive support to families. Education and Training in Mental Retardation 1988;23:261-272.

(64) Grotberg EH. Resilience for today: Gaining strength from adversity. Westport, Connecticut: Prager Publishers, 2003, $1-29$.

(65) Hiew CC. Child resilience: Conceptual and evaluation issues. Proceedings of the 23rd Child Learning Forum, Osaka. 1998, 21-24.

（66）山本悦代，位田 忍，峯一二三．在宅医療児を抱元る 家族の心理的側面の実態調査 家族の心理的負担の 軽減之親子の関係性の育みのために。大阪府立母子保 健総合医療センター雑誌 2013;29:96-102.

(67) Larson E. Reframing the meaning of disability to families: the embrace of paradox. Soc Sci Med 1998;47:865-875.

（68）山本則子，石垣和子，国吉緑他. 高齢者家族に打忷る 介護の肯定的認識と生活の質 $(\mathrm{QOL})$ ：生きがい感お よび介護継続意思との関連：続柄別の検討. 日本公衆 衛生学雑誌 2002;49:660-671.

（69）石井秀宗. 統計分析のここが知りたい一保健・看護 ・ 心理・教育系研究のまとめ方．東京：文光堂，2006, 14-17.

(70) Greeff AP, Vansteenwegen A, Gillard J. Resilience in Families Living with a Child with a Physical Disability. Rehabil Nurs 2012;37:97-104.

(71) Omori M, Yoshioka S. Comparisons of Emotional Intelligence, Mental Health and Ego-resilience Between Mothers of Children/Adolescents With and Without Disabilities. Shimane Journal of Medical Science 2016;33:17-25. 